\title{
Primary mediastinal hemangiopericytoma
}

\section{A Chnaris ${ }^{1}, \mathrm{~N}$ Barbetakis*2, A Efstathiou ${ }^{3}$ and I Fessatidis ${ }^{3}$}

\author{
Address: ${ }^{1}$ Cardiothoracic Surgery Department, G. Papanikolaou General Hospital, Thessaloniki, Greece, ${ }^{2}$ Cardiothoracic Surgery Department, \\ Theagenio Cancer Hospital, Thessaloniki, Greece and ${ }^{3}$ Cardiothoracic Surgery Department, Geniki Kliniki, Thessaloniki, Greece \\ Email: A Chnaris - akisxnaris@yahoo.gr; N Barbetakis* - nibarb@otenet.gr; A Efstathiou - akhna@otenet.gr; \\ I Fessatidis - fessatidis@genikikliniki.gr \\ * Corresponding author
}

Published: 27 April 2006

World Journal of Surgical Oncology2006, 4:23 doi:10.1 186/1477-78|9-4-23

This article is available from: http://www.wjso.com/content/4/I/23

2006Chnaris et al; licensee BioMed Central Ltd.

This is an Open Access article distributed under the terms of the Creative Commons Attribution License (http://creativecommons.org/licenses/by/2.0), which permits unrestricted use, distribution, and reproduction in any medium, provided the original work is properly cited.

Received: 26 December 2005

Accepted: 27 April 2006

\begin{abstract}
Background: Hemangiopericytoma is a rare mesenchymal neoplasm, accounting for about $\mathrm{I} \%$ of vascular tumors The tumor occurs most commonly in the skin, subcutaneous soft tissues, muscles of the extremities, retroperitoneum but rarely in the lung, trachea or mediastinum.

Case presentation: A rare case of primary mediastinal hemangiopericytoma is presented. A 72year-old woman was treated by complete surgical resection of the tumor. Details of the clinical and radiographic feature are presented. The patient's postoperative course was uneventful with no evidence of recurrence 9 months after the operation.

Conclusion: Hemangiopericytoma is an uncommon, potentially malignant tumor originating from pericytes in the small vessels and surgical radical excision is the treatment of choice, although the criteria for determining the area of resection have not been established. International literature has demonstrated that recurrent disease usually occurs within 2 years and therefore a long-term careful follow-up is required.
\end{abstract}

\section{Background}

Hemangiopericytoma is a rare mesenchymal neoplasm, accounting for about $1 \%$ of vascular tumors [1]. Hemangiopericytoma is known to be derived from the vascular pericyte and was first reported by Stout and Murray in 1942 [2]. The tumor occurs most commonly in the skin, subcutaneous soft tissues, muscles of the extremities, retroperitoneum but rarely in the lung, trachea or mediastinum [3]. Herein, a surgical case of primary mediastinal hemangiopericytoma is presented.

\section{Case presentation}

A 72-year-old woman was referred to our institution complaining of dyspnea, cough and chest tightness for the last two months. Physical examination indicated tachypnea, orthopnea and use of accessory respiratory muscles. Laboratory studies were essentially within normal limits. A chest X-ray revealed a homogenous opacity occupying lower two-thirds of the left hemithorax and causing contralateral shifting of the mediastinum and heart (Figure 1). Thoracentesis was performed in order to palliate respiratory problems. One thousand eight hundred (1800) $\mathrm{ml}$ of serosanguinous fluid were aspirated. Cytologic examination revealed an exudate with no signs of malignancy. Culture of the aspirated pleural fluid was also negative. A computed tomographic scan (CT) of the chest revealed a large solid tumorous mass measuring $7.3 \times 2.3 \mathrm{~cm}$ located in the posterosuperior mediastinum on the left side associated with pleural effusion (Figure 2). In order to perform preoperative staging of the tumor, the patient underwent 


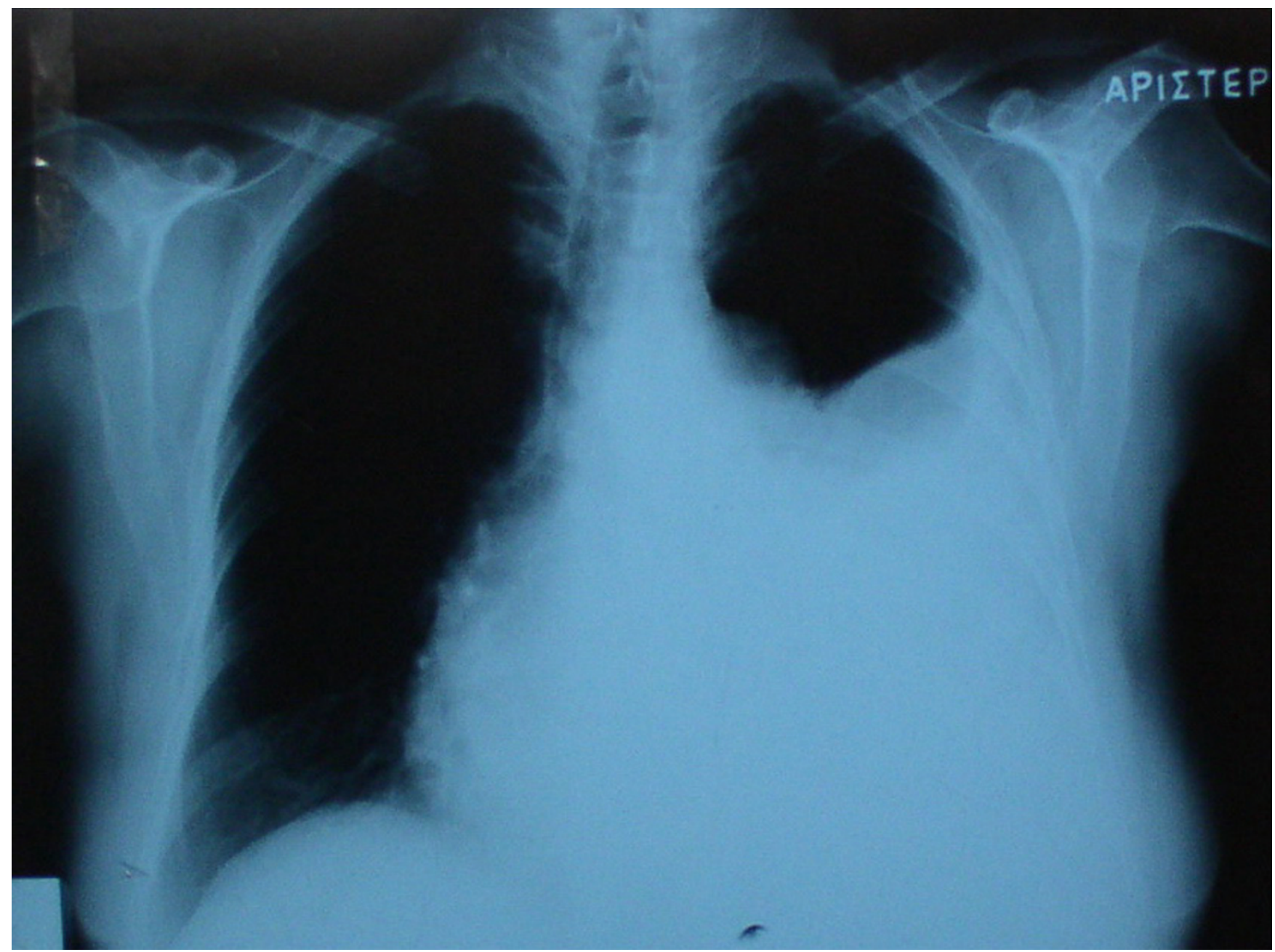

Figure I

Chest X-ray showing an abnormal shadow associated with ipsilateral pleural effusion.

CT scans of brain, upper abdomen, a bone scan and broncoscopy. All were normal. The tumor markers alpha-fetoprotein (AFP), carcinoembryonic antigen (CEA), CA 19-9, neuron-specific enolase (NSE) and squamous cell carcinoma antigen were within normal limits. The mass seemed to be resectable and surgical approach was suggested to the patient.

The patient underwent left posterolateral thoracotomy through $5^{\text {th }}$ intercostal space. During the operation, the mass appeared to have mediastinal origin and was highly vascularized. There was no involvement of vital mediastinal structures and the surrounding lung parenchyma was compressed by the tumor. Six hundred $\mathrm{ml}$ of sanguinous pleural fluid were aspirated. Despite the persistent bleeding during dissection the tumor was resected. The mass measured $7 \times 3 \times 2.5 \mathrm{~cm}$ and weighed $210 \mathrm{~g}$. Grossly the resected specimen was a smooth, friable encapsulated mass with focal hemorrhages. The cut surface was smooth, elastic and pale brown. Microscopic examination showed round and spindle cells surrounded by thin-walled, endothelium-lined vascular channels, giving a "staghorn" appearance to the vessels as typically seen in hemangiopericytoma (Figure 3). The low-mitotic activity and the absence of clear nuclear pleomorphism were suggestive of a low-grade malignant tumor. The tumor cells were immunoreactive only for anti-smooth-muscle-actin protein (Figure 4).

The postoperative course was uneventful and the patient was discharged home on postoperative day 9. Postoperative chemoradiotherapy was recommended but the 


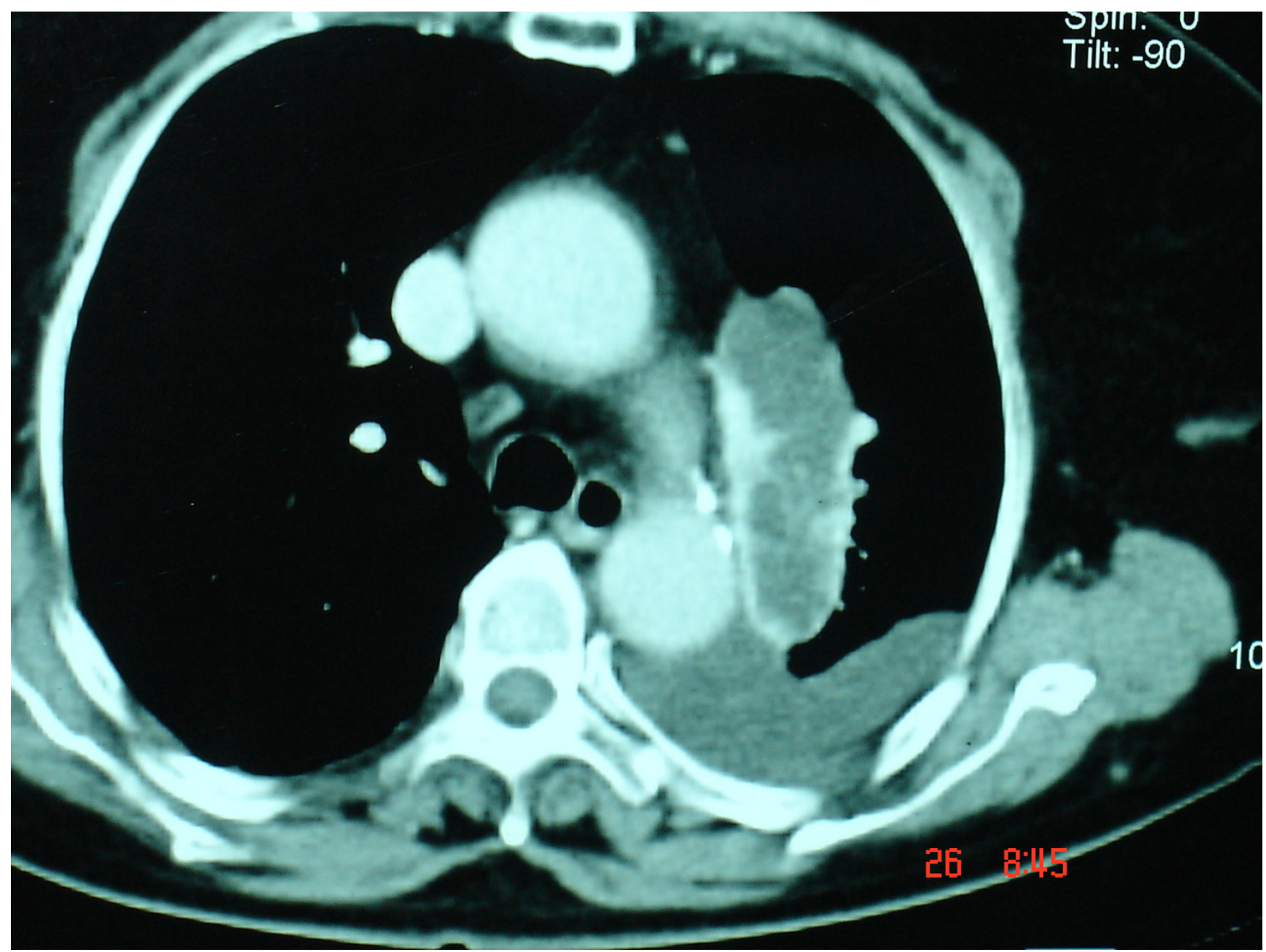

Figure 2

Preoperative computed tomographic scan demonstrated a tumor mass located in the mediastinum next to descending aorta and associated with pleural effusion.

patient denied any further treatment. Nine months after the operation the patient is alive and well without evidence of recurrence of the disease.

\section{Discussion}

Hemangiopericytoma is an uncommon, potentially malignant tumor originating from pericytes in the small vessels. Intrathoracic hemangiopericytoma usually arises from pericytes that surround the basement membrane of capillaries and small venules within the lung parenchyma [3]. Our case was an intrathoracic mediastinal hemangiopericytoma, which is extremely rare. Only a few isolated case reports are available in the literature [4-7], whereas the intrapulmonary variety of the same tumor is relatively more common.
Hemangiopericytoma has no uniform clinical or radiographic features, usually affects older individuals, and mostly presents as an asymptomatic, non-calcified solitary mass on chest X-ray. These tumors are composed of closely-packed spindle cells and prominent vascular channels. The histological differential diagnosis includes many mesenchymal tumors, such as the solitary fibrous tumor and the synovial sarcoma [3]. No single clinical or histological feature including histological type or DNA ploidy allows prediction of biologic aggressiveness [8]. Malignant hemangiopericytoma is recognized by its increased mitotic rate, tumor size and foci of hemorrhage and necrosis [3].

Immunohistochemically, hemangiopericytomas are known to show a positive response to antibodies against vimentin and type IV collagen and a negative response to 


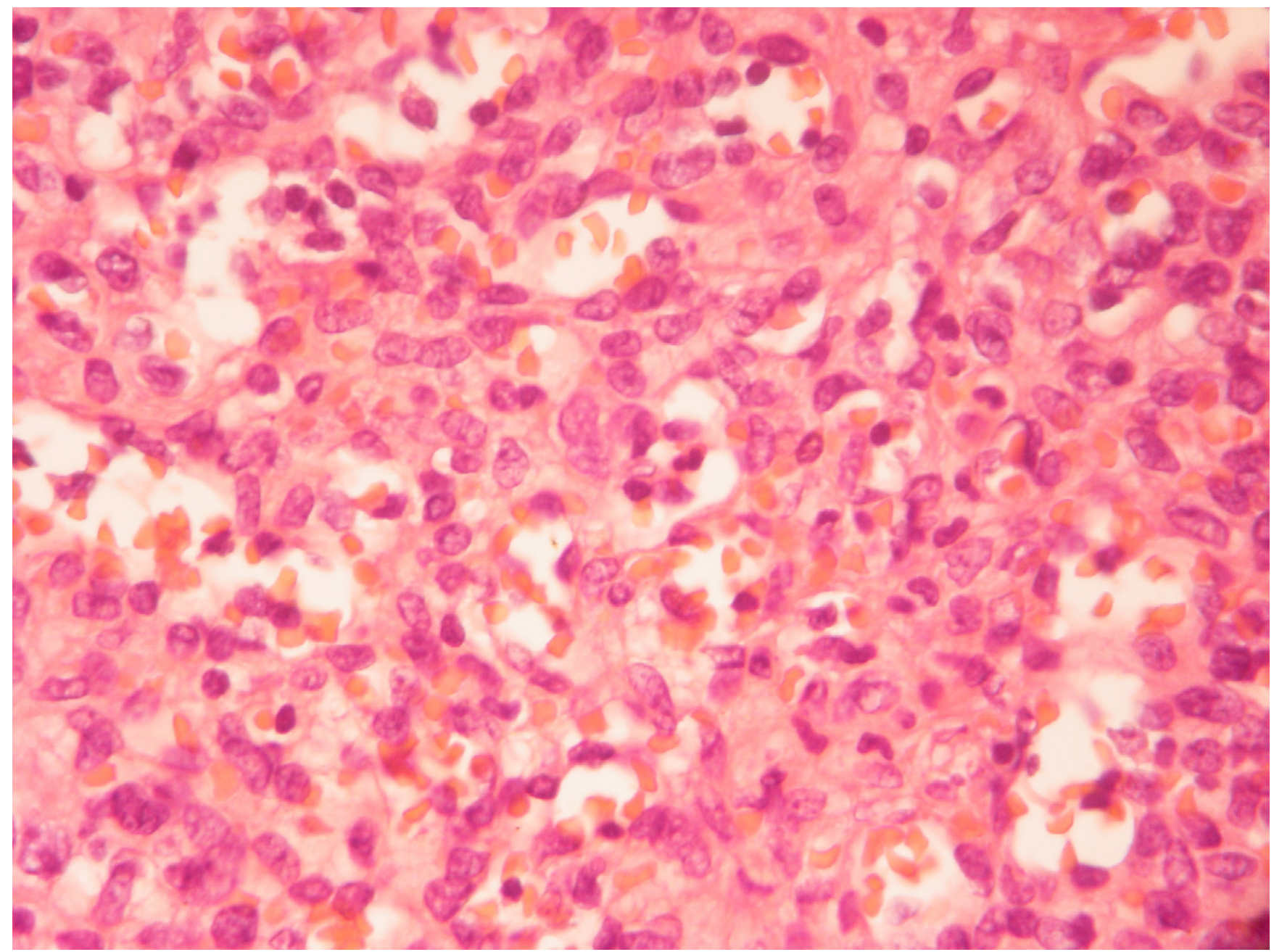

Figure 3

Round and spindle cells surrounded by thin-walled, endothelium-lined vascular channels, giving a "staghorn" appearance to the vessels as typically seen in hemangiopericytoma (Hematoxylin and eosin stain $\times 400$ ).

VIII-related antigen, S-100 protein, neuron specific enolase, carcinoembryonic antigen, desmins, laminin and cytokeratins [9].

A special consideration concerns the preoperative diagnosis. When a mass appears to be radiologically resectable, many authors perform a thoracotomy without histological diagnosis. Previous reports propose an attempt to obtain a preoperative diagnosis even in tumors that are clearly resectable if high vascularization is suspected on imaging techniques $[10,11]$.

Surgical radical excision is the treatment of choice for hemangiopericytomas, although the criteria for determining the area of resection have not been established. Hansen and colleagues stated that it was necessary to consider all hemangiopericytomas as malignant and perform extended surgery [12]. During the resection, it is important to look for invasion of the surrounding lung tissue and to avoid intrathoracic spread of tumor cells by manual examination. With respect to adjuvant therapy, chemotherapy or radiotherapy have been recommended but is considered to be almost ineffective [3]. On the other hand Rusch et al., reported that combination therapy or single therapy with adriamycin was effective against metastases [13]. Jalal and Jeyasingham reported that preoperative radiotherapy of large hemangiopericytomas on the chest wall significantly reduced the vascularity of the tumor and made complete resection much easier [14]. Some authors have proposed an innovative approach of treatment, which includes complete surgical resection along with intraoperative and postoperative radiotherapy, whereas others have recommended that radiotherapy may be used palliatively for local tumor recurrence or superior vena 


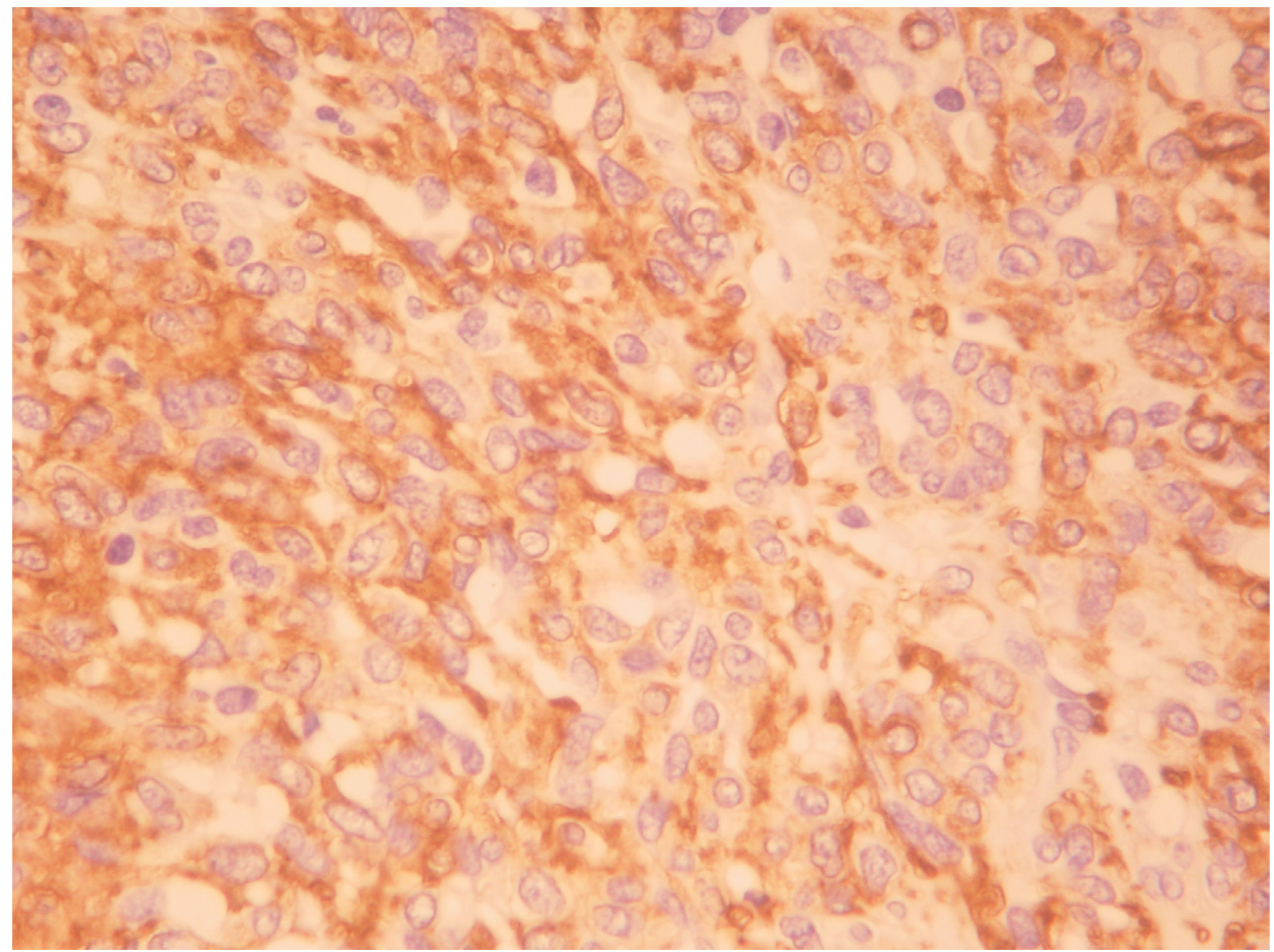

Figure 4

Tumor cells clearly positive for a-SMA (anti-smooth-muscle-actin) protein $(\times 400)$.

cava obstruction $[13,15,16]$. Morandi et al., recommended preoperative percutaneous embolization of hypervascular mediastinal tumors, in order to allow a safe complete removal of the lesion later [17].

The 5-year survival of patients with hemangiopericytoma originating in any organ has been reported to be $85 \%$, whereas the survival of patients with a tumor of pulmonary origin is $30-35 \%$. Approximately $50 \%$ of hemangiopericytomas have been reported to recur within 5 years $[3,12]$. It has been demonstrated that recurrent disease usually occurs within 2 years after initial treatment and recurrences are commonly found in the thorax, either in the pulmonary parenchyma or in the pleura. Distant metastases to liver, brain and bone have also been reported [12].

\section{Conclusion}

Hemangiopericytoma is rare vascular slow-growing tumor with high local recurrence and the long-term prognosis is poor because of its propensity to recur. Surgical radical excision is the treatment of choice despite the fact that the risk of intraoperative uncontrollable bleeding is high. Local or distant recurrence is commonly seen and a longterm careful follow-up is required.

\section{Competing interests}

The author(s) declare that they have no competing interests.

\section{Authors' contributions}

$\mathrm{AC}, \mathrm{NB}, \mathrm{AE}$ took part in the care of the patient and contributed equally in carrying out the medical literature search and preparation of the manuscript. IF participated 
in the care of the patient and had the supervision of this report. All authors approved the final manuscript.

\section{Acknowledgements}

Written consent of the patient was obtained for publication of this case report.

\section{References}

I. Hart LL, Weinberg JB: Metastatic hemangiopericytoma with prolonged survival. Cancer 1987, 60:916-920.

2. Stout AP, Murray MR: Hemangiopericytoma: a vascular tumor featuring Zimmerman's pericytes. Ann Surg 1942, I I 6:26-33.

3. Espat NJ, Lewis JJ, Leung D: Conventional hemangiopericytoma: modern analysis of outcome. Cancer 2002, 95: 1746-|75|.

4. Simonton SC, Swanson PE, Watterson J, Priest JR: Primary mediastinal hemangiopericytoma with fatal outcome in a child. Arch Pathol Lab Med 1995, I 19:839-84I.

5. Hayashi A, Takamori S, Tayama K, Mitsuoka M, Tamura K, Shirouzu K, Fujimoto K, Watanabe J: Primary hemangiopericytoma of the superior mediastinum: a case report. Ann Thorac Cardiovasc Surg 1998, 4:283-284.

6. Mori M, Nakanishi N, Furuya K: Hemangiopericytoma of the mediastinum causing spontaneous hemothorax. Ann Thorac Surg 1994, 58:1525-1527.

7. Gomez Finana MS, Paya Perez L, Parede Osaelo JR, Aranda Lopez I, Massuti Sureda B, Talavera Sanchez J: Hemangiopericytoma of the soft palate and mediastinum: a case report. Acta Otorrinolaringol Esp 1994, 45:465-468.

8. Fukunaga M, Shimoda T, Nikaido T, Ushigom S, Ishikawa E: Soft tissue vascular tumor. A flow cytometric DNA analysis. Cancer | 993, 7 I:2233-2241.

9. Yoshida M, Morita M, Kakimoto S, Kawakami M, Sasaki S: Primary hemangiopericytoma of the trachea. Ann Thorac Surg 2003, 76:944-946.

10. Baldo X, Sureda C, Gimferrer JM, Belda J: Primary mediastinal leiomyoma. Eur J Cardiothorac Surg 1997, I I:574-576.

II. Fiumara E, D'Angelo V, Florio FP, Nardella M, Biscelia M: Preoperative embolization in surgical treatment of spinal thoracic dumpbell schwannoma. J Neurosurg Sci 1996, 40:153-156.

12. Hansen CP, Francis D, Bertelsen S: Primaryhemangiopericytoma of the lung. Scand I Thorac Cardiovasc Surg 1990, 24:89-92.

13. Rusch VW, Shuman WP, Schmidt R, Laramore GE: Massive pulmonary hemangiopericytoma. An innovative approach to evaluation and treatment. Cancer 1989, 64:1928-1936.

14. Jalal A, Jeyasingham $\mathrm{K}$ : Massive intrathoracic extrapleural hemangiopericytoma: deployment of radiotherapy to reduce vascularity. Eur J Cardiothorac Surg 1999, 16:378-38I.

15. Mira JG, Chu FCH, Fortner JG: The role of radiotherapy in the management of malignant hemangiopericytoma - report of II cases and review of the literature. Cancer 1975, 39:1254-1259.

16. Jha N, McNeese M, Barkley HT Jr, Kong J: Doesradiotherapy have a role in hemangiopericytoma management? Int J Radiat Oncol Biol Phys 1987, 13:1399-1402.

17. Morandi U, Stefani A, De Santis M, Paci M, Lodi R: Preoperative embolization in surgical treatment of mediastinal hemangiopericytoma. Ann Thorac Surg 2000, 69:937-939.
Publish with Biomed Central and every scientist can read your work free of charge

"BioMed Central will be the most significant development for disseminating the results of biomedical research in our lifetime. "

Sir Paul Nurse, Cancer Research UK

Your research papers will be:

- available free of charge to the entire biomedical community

- peer reviewed and published immediately upon acceptance

- cited in PubMed and archived on PubMed Central

- yours - you keep the copyright

Submit your manuscript here:

http://www.biomedcentral.com/info/publishing_adv.asp
BioMedcentral 